\title{
HEMATOPOIETIC STEM CELL GENE THERAPY FOR INHERITED MONOGENIC DISEASES AND ITS IMPLICATIONS FOR FUTURE GENE THERAPY TRIALS IN TURKEY
}

\author{
Gülen GÜNEY ESKEN ${ }^{1,2}$, Özgür Doğuş EROL ${ }^{1,2}$, Fatima AERTS-KAYA $^{1,2^{*}}$ \\ ${ }^{1}$ Hacettepe University, Graduate School of Health Sciences, Department of Stem Cell Sciences, Ankara, TURKEY \\ ${ }^{2}$ Hacettepe University, Center for Stem Cell Research and Development, PEDISTEM, Ankara, TURKEY \\ *Corresponding author: ORCID ID: orcid.org/0000-0002-9583-8572, e-mail: fatimaaerts@ yahoo.com
}

Cite this article as:

Güney Esken G., Erol Ö.D., Aerts-Kaya F. 2019. Hematopoietic Stem Cell Gene Therapy for Inherited Monogenic Diseases and Its Implications for Future Gene Therapy Trials in Turkey. Trakya Univ J Nat Sci, 20(Special Issue): S17-S32, DOI: 10.23902/trkjnat.483402

Received: 15 November 2018, Accepted: 19 January 2019, Published: 1 February 2019

\begin{abstract}
Stem cell therapy offers a great advantage for the development of new treatments in the field of regenerative and restorative medicine. However, the use of stem cell therapies and their clinical indications can even be further improved using genetic modification of the cells. Due to the high level of consanguineous marriages in Turkey, the country suffers from an increased frequency of inborn genetically inherited diseases. Treatment of these diseases is difficult, since 1) diagnosis is often delayed in rural areas, 2) distance to specialized centers may be considerable, 3) treatment may require frequent hospital visits and 4) treatment procedures are often both invasive and expensive.
\end{abstract}

Here, we discuss the current status of gene therapy of hematopoietic stem cells (HSCs) for rare, inherited monogenic diseases and the advantages to use these cells as an alternative treatment option for patients in Turkey. We discuss results of clinical trials using retroviral and lentiviral gene therapy for the treatment of immune deficiencies, hemoglobinopathies and several enzyme deficiencies, new developments in the field of the HSC gene therapy to improve safety and efficacy and recommendations for the future.

Key words: Gene Therapy, hematopoietic stem cells, lentiviral vectors, biosafety, inherited monogenic diseases.

Özet: Kök hücre tedavisi rejeneratif tıp ve restoratif tıp alanlarında yeni tedavilerin geliştirilmesi için büyük avantaj sağlamaktadır. Böylelikle, kök hücre tedavilerinin kullanımı ve bunların klinik endikasyonları hücrelerin genetik modifikasyonu ile geliştirilebilmektedir. Türkiye'deki akraba evlilik oranının fazla olmasından dolayı, yenidoğan genetik kalıtsal hastalıkların insidası artmaktadır ve bu durum bir sorun teşkil etmektedir. Bu hastalıkların tedavi edilmesi; 1) kırsal bölgelerde hastalığın sıklıkla geç teşhisi, 2) Özel merkezlerin uzak olması, 3) Tedavilerin sık hastane kontrolü gerektirmesi, 4) Tedavi prosedürlerinin hem pahalı hem de invazif olması nedenleriyle zordur.

Bu makalede nadir kalıtsal monogenik hastalıklar için hematopoetik kök hücre (HKH) gen tedavisinin güncel durumları ve Türkiye'deki hastalar için alternatif bir tedavi seçeneği olarak kullanımının avantajları tartışılacaktır. İmmun yetmezlikler, hemoglobinopatiler, birçok enzim eksikliklerinde retroviral ve lentiviral gen tedavi klinik çalışma sonuçları, HKH gen tedavisi alanındaki yeni gelişmeler, güvenlik ve etkinliğin artırılması ve gelecekteki öneriler tartışılacaktır.

\section{Introduction}

Current treatment strategies for inherited monogenic $\underline{\text { diseases }}$

The rationale for stem cell gene therapy for inherited diseases is to provide the genome with a healthy copy of the gene as an addition to or as a replacement of the mutated gene in order to develop permanently curative treatment options for inherited monogenic diseases. Many hematopoietic diseases and enzyme deficiencies can be currently treated with hematopoietic stem cell (HSC) transplantation (Biffi 2017, Majhail et al. 2015, Ringden et al. 2018, Wynn 2011). In addition, Enzyme
Replacement Therapy (ERT) has been developed for some of the enzyme deficiencies/storage diseases, such as Fabry disease, Gaucher disease, Pompe disease, Lysosomal acid lipase deficiency, Mucopolysaccharidosis (MPS-I: Hurler Syndrome; MPSII: Hunter Syndrome; MPS-IV: Morquio Syndrome; MPS-VI: Maroteaux-Lamy syndrome), as well as for severe combined immunodeficiency (SCID) caused by adenosine deaminase deficiency (ADA-SCID) (Beck 2018, Gaspar et al. 2009). However, not all patients have an available matched donor, and even if a donor is available, the HSC transplantation will fail when 
expression levels of the enzyme in HSCs are too low to expect benefit, or may result in graft-versus-host-disease (GvHD) when cells derived from the donor induce immunological damage of tissues/organs of the patient. In addition, ERT often involves life-long weekly-monthly treatments requiring frequent (out-patient clinic) hospital admissions and effects of ERT typically decline in time due to immune responses against the drugs, resulting in even more frequently needed infusions. Moreover, the inability of enzymes to efficiently cross the blood-brain barrier (BBB) limits the efficacy of both HSC transplantation and ERT in enzyme deficiencies that affect the central nervous system (CNS).

\section{Development of novel treatments for rare diseases}

Rare or orphan diseases are diseases which affect fewer than 200,000 people (US definition) or less than 5 individuals per 10,000 of the population (EU definition) and as a result are not the focus of interest of the pharmaceutical industry because of the little financial incentive to develop new medications (Sharma et al. 2010). Approximately $70 \%$ of about 6,000-8,000 diseases which are considered rare are genetic in their origins. To encourage pharmaceutical companies to invest in orphan drug development, the US introduced the US Orphan Drug Act in 1983 to provide suitable tax initiatives on clinical trials and 7 years of marketing exclusivity for drugs developed for conditions that occur only rarely in the US (Shah 2006). Since then, over 250 orphan drugs have been approved by the US Food and Drug Administration (FDA) and in its footsteps, a number of other countries introduced similar legislation (Singapore in 1991, Japan in 1993 and Australia in 1998) (Shah 2006). In 2000, the European Parliament and Council Regulation (EC) adopted the orphan medicinal products legislation with regulations No 141/2000 (EC No 141/2000) and No 847/2000 (EC No 847/2000). The EMEA (now EMA), through its Committee for orphan medicinal products (COMP) is responsible for reviewing designation applications. During the first five years of implementation (from April 2000 to April 2005), 458 applications for orphan designation were submitted, resulting in 268 products being designated for more than 200 different rare conditions (EC No 141/2000). The predominant therapeutic areas covered were cancer (36\%), metabolic disorders $(21 \%)$, immunology (11\%), and cardiovascular and respiratory disorders $(12 \%)$ (EC No $141 / 2000)$. Of these, $54 \%$ of the medicinal products designated had potential for pediatric use, $11 \%$ solely for pediatric and $43 \%$ for both adult and pediatric use (EC No 141/2000). Unfortunately, research funds barely cover the costs of the scientific community and development of new innovative medicinal products is expensive. It is estimated that the average cost of developing a new drug ranges from 400 to 800 million USD depending on the therapeutic class of the drug (DiMasi et al. 2003). Commercially, the costs for the development of a drug for an orphan disease often do not outweigh the expected returns. As a result, prices may be high and access may vary from country to country and depend on the availability of health insurance or governemental reimbursements.

\section{Gene therapy for inherited monogenic diseases}

After an initial period of low success rates with unforeseen severe adverse effects and poor public understanding resulted in the (temporarily) seizing of ongoing clinical trials, gene therapy is now becoming more and more attractive as a treatment option for rare, inherited monogenic diseases. Not only because the treatment is (intended to be) curative and a single treatment should be sufficient, but also because the costs of a single treatment would be significantly lower than the costs of life-long symptomatic treatment. The use of genetically modified autologous HSCs to treat monogenic diseases is based on the assumption that 1) the disease itself can be treated by the transfer of healthy HSCs because the hematopoietic stem cell and/or its progeny are affected, e.g. primary immune deficiencies (PID) or diseases involving hemoglobin synthesis (hemoglobinopathy), 2) addition of a single normal copy of the mutated gene is sufficient to correct the deficiency or alleviate its symptoms or 3 ) overexpression of the gene in hematopoietic cells results in sufficient levels of the missing protein, resulting in cross-correction of affected cells and clearance of the accumulated substrate, e.g. enzyme deficiencies. In addition, gene therapy in mitotic cells, such as HSCs, lymphoid progenitor cells and mature lymphocytes requires the use of a vector system such as retrovirus or lentivirus which are able to integrate in the host genome. This property ensures replication of the therapeutic transgene during cell division and stable transmission to its progeny. Although a substantial part of gene therapy studies and clinical trials $(64.5 \%)$ focuses on the treatment of cancer, here we will address only gene therapy for inherited monogenic diseases and its foreseen use in the Turkish population. Discussion of gene therapy for multifactorial diseases or malignancies is beyond the scope of this article and has been reviewed recently by Sanlioglu (2016).

Development of retroviral and lentiviral vectors for HSC gene therapy

The gammaretroviral genome $(\gamma \mathrm{RV})$ consists of a ssRNA and is approximately 7-10 kb in length. Retroviral vectors can stably integrate into the host genome using the enzymes reverse transcriptase (RT), which turns ssRNA into ssDNA and integrase (IN), which facilitates integration into the host genome. Gammaretroviral vector proviral DNA consists of a 5' and a 3' long terminal repeat (LTR), consisting of a U3, $\mathrm{R}$ and a U5 region, as well as open reading frames (ORF) for structural (Naldini et al. 1996), replication (pol) (Puthenveetil et al. 2004) and envelope proteins (Maetzig et al. 2011). The first retroviral constructs have been developed almost 40 years ago and were initially based on murine leukemia virus (MLV) (Shimotohno \& Temin 1981, Wei et al. 1981). 


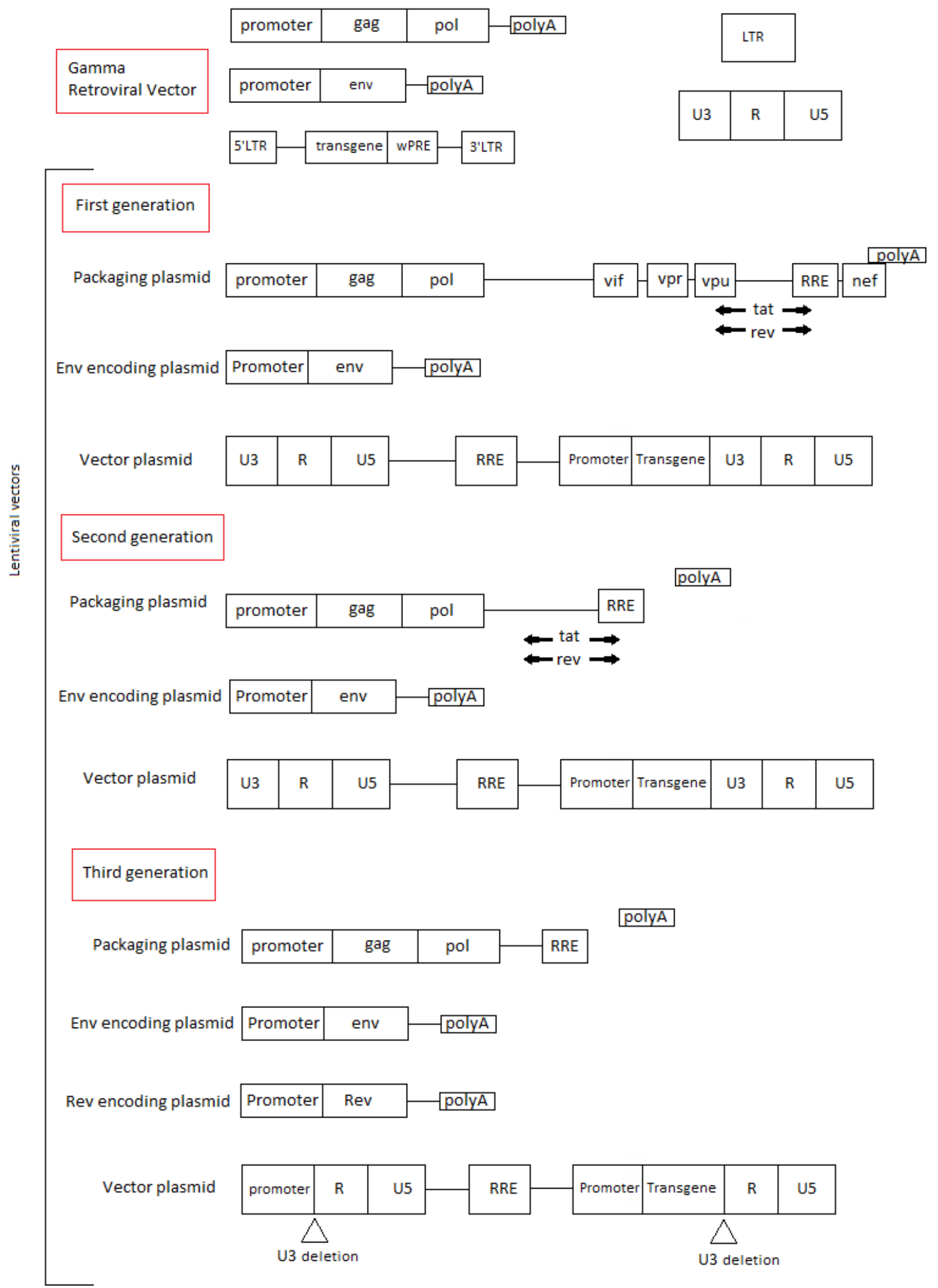

Fig. 1. Development of different generations of retroviral and lentiviral vectors. To generate second ( $\Delta$ Vpr, Vif, Vpu, Nef) and third (also $\Delta$ Tat) generation vector systems, genes not required for transduction were deleted. To improve safety, the rev gene was deleted from the packaging construct and the promoter-enhancer sequences in the 5'LTR U3 region of the integrated transgene were deleted, creating self-inactivating (SIN) lentiviral vectors. 
Table 1. Design and safety features of different retroviral and lentiviral constructs.

\begin{tabular}{|c|c|c|c|c|}
\hline Vectors & Plasmids & Features & $\begin{array}{l}\text { Insertional } \\
\text { mutagenesis }\end{array}$ & Ref \\
\hline$\gamma \mathbf{R V}(\mathbf{M L V})$ & $\begin{array}{l}\text { 1) gag, pol, env; } \\
\text { 2) vector genome and } \\
\text { transgene }\end{array}$ & $\begin{array}{l}\text { genome integration, restricted to } \\
\text { dividing cells, RCR }\end{array}$ & + & (Maetzig et al. 2011) \\
\hline $\begin{array}{c}\text { First } \\
\text { generation } \mathrm{LV}\end{array}$ & $\begin{array}{l}\text { 1) gag, pol, rev, vpi, vpu, vpr, } \\
\text { nef; 2) env; 3) vector genome } \\
\text { and transgene }\end{array}$ & $\begin{array}{l}\text { genome integration, dividing and } \\
\text { non-dividing cells, RCL }\end{array}$ & + & (Naldini et al. 1996) \\
\hline $\begin{array}{c}\text { Second } \\
\text { generation } \mathrm{LV}\end{array}$ & $\begin{array}{l}\text { 1) gag, pol, rev, } \Delta v p r ; 2) \text { env; } \\
\text { 3) vector genome and } \\
\text { transgene }\end{array}$ & $\begin{array}{l}\text { genome integration, dividing and } \\
\text { non-dividing cells, low RCL }\end{array}$ & + & (Zufferey et al. 1997) \\
\hline $\begin{array}{l}\text { Third } \\
\text { generation } \\
\text { SIN-LV }\end{array}$ & $\begin{array}{l}\text { 1) gag, pol; 2) env; 3) rev; } \\
\text { 4) vector genome and } \\
\text { transgene }\end{array}$ & $\begin{array}{l}\text { self-inactivating, genome integration, } \\
\text { dividing and non-dividing cells, very } \\
\text { low RCL }\end{array}$ & $+/-$ & (Dull et al. 1998) \\
\hline $\begin{array}{l}\text { Fourth } \\
\text { generation } \\
\text { SIN-LTR1, } \\
\text { Lenti-X }\end{array}$ & $\begin{array}{l}\text { 1) gag; 2) } \Delta v p r, \text { pol; 3) tat, rev; } \\
\text { 4) env; 5) vector genome and } \\
\text { transgene }\end{array}$ & $\begin{array}{l}\text { Genome integration, dividing and } \\
\text { non-dividing cells, very low RCL }\end{array}$ & $+/-$ & $\begin{array}{l}\text { (Berkhout 2017, } \\
\text { Vink et al. 2017) }\end{array}$ \\
\hline NILV & $\begin{array}{l}\text { 1) gag, } \Delta \text { pol (deletion of } \\
\text { integrase); 2) env; 3) vector } \\
\text { genome and transgene }\end{array}$ & $\begin{array}{l}\text { No genome integration, dividing and } \\
\text { non-dividing cells }\end{array}$ & - & $\begin{array}{l}\text { (Banasik \& McCray } \\
\text { 2010, Shaw \& } \\
\text { Cornetta 2014, } \\
\text { Wanisch \& Yanez- } \\
\text { Munoz 2009) }\end{array}$ \\
\hline
\end{tabular}

Since retroviruses use receptor binding to transfer their genetic material into specific somatic cells, this mechanism can be modified and used to transfer transgenes for therapeutic intervention into specific target cells, eg. HSCs and treat monogenic diseases. To prevent the generation of replication competent retrovirus (RCR) in genetically modified cells, the genes for Gag/Pol and Env need to be separated using a split packaging design. The resulting retroviral vector contains the packaging signal $(\psi)$, the primer binding site (PBS) and the long terminal repeats (LTR), but carries the transgene instead of the Gag/Pol and Env genes, which are expressed by separate plasmids. After integration of the retroviral DNA into the host cell chromosomal DNA, the proviral DNA is replicated during the cell cycle, and subsequently passed to the cell's progeny (Buchschacher \& Wong-Staal 2000, Schambach et al. 2009, Sinn et al. 2005). However, $\gamma$ RV vectors can only infect dividing cells and permanent insertion has been shown to be associated with a risk for insertional mutagenesis (Hacein-Bey-Abina et al. 2003, Temin 1990).

In the 1990s, Naldini et al. (1996) developed lentiviral vectors based on the Human immunodeficiency virsus-1 (HIV-1). Lentivirus (LV) has the same basic biological features as $\gamma \mathrm{RV}$ (Nisole \& Saib 2004). However, LV vectors have the additional ability to transfer genetic material to both dividing and non-dividing cells and are considered safer than $\gamma \mathrm{RV}$ (Lewis \& Emerman 1994, Schambach et al. 2013). Lentiviruses, when compared to oncogenic $\gamma \mathrm{RV}$, have a more complex genome and have two regulatory genes, tat and rev, which are indispensible for viral replication and four unneccessary accessory genes, vif, vpr, vpu and nef, which are key for in vivo replication and pathogenesis of HIV-1 but not required for in vitro viral expansion or transduction.

The first generation LV vectors developed by Naldini et al. (1996) consisted of a three plasmid system. The first plasmid contained the genes for gag, pol, tat and rev, as well as the accessory genes and the packaging signal, the second plasmid encoded the heterologous env protein, which determines vector tropism and the third plasmid included the transgene or gene of interest (GOI) (Naldini et al. 1996). To generate second ( $\Delta \mathrm{Vpr}$, Vif, Vpu, Nef) (Dull et al. 1998) and third (also $\Delta$ Tat) (Miyoshi et al. 1999) generation vector systems, genes not required for transduction were deleted and to increase safety, the rev gene was also deleted from the packaging construct, making expression of gag and pol strictly dependent on Rev complementation in trans on a separate plasmid (Dull et al. 1998). Therefore, in third generation LV vectors, generation of RCL requires two recombination events. Furthermore, as an additional safety feature, the promoter-enhancer sequences in the 5'LTR U3 region of the integrated transgene were deleted, creating selfinactivating (SIN) lentiviral vectors with a decreased risk for generation of replication competent lentivirus (RCL) (Zufferey et al. 1997). However, third generation LV vector genomic RNA still requires sequences to partially overlap wild-type HIV-1 gag and env genes for packaging into vector particles. To circumvent this problem and further decrease the total HIV-1 content in the LV vectors, a fourth generation LTR1 vector has been designed to prevent potential transfer of HIV-1 packaging sequences 
to host cells by building a system wherein reversetranscription results in single strand transfer, instead of the usual two (Berkhout 2017, Vink et al. 2017). Here, the lentiviral vector was further modified by placing several essential RNA signals (PBS- $\Psi$-RRE) outside the viral backbone and downstream of the 3'LTR (Berkhout 2017, Vink et al. 2017). Alternatively, in the Lenti-X packaging system the $\mathrm{gag}$ and $\mathrm{pol}$ genes are further separated onto two plasmids, requiring at least three low-frequency recombination events to generate RCL. Although retroviral vectors were shown to have a preference for integrations near specific proto-oncogenes (LMO2, CCND2, MSD1-EVI1, PRDM16, SETBP1) (Deichmann et al. 2007, Howe et al. 2008, Schwarzwaelder et al. 2007), SIN-LV vectors, which are considered less genotoxic than the $\gamma \mathrm{RV}$ vectors, also carry non-negligible risks of insertional transformation (Modlich et al. 2009). Therefore, the last major advance has been the development of non-integrating LV (NILV) or integration deficient lentiviral (IDLV) vectors. This design aims to remove genome integration and eliminate any risk of recombination and insertional mutagenesis. NILV vectors can be made by inducing mutations in pol that alter the integrase protein and affect its function, or alternatively by deletion of a $12 \mathrm{bp}$ fraction of the 5'LTR U3 unit and an $11 \mathrm{bp}$ fraction of the 3'LTR U5 resulting in mutations in the integrase DNA attachment site (LTR att sites) (Banasik \& McCray 2010). Despite these modifications, the vectors maintain the ability to enter target cells, perform reverse transcription, transport the preintegration complex (Hacein-Bey Abina et al.) into the nucleus and efficiently express their transgene product. The modifications also do not affect the capacity of NILV vectors to efficiently infect both dividing and non-dividing cells (Shaw \& Cornetta 2014, Wanisch \& Yanez-Munoz 2009). The design and safety features of different RV and LV vectors are summarized in Table 1 and the most commonly used vector constructs are depicted in Fig. 1.

\section{Status quo of ex vivo gene therapy for inherited monogenic diseases}

\section{Primary immune deficiencies}

Primary immune deficiencies (PIDs) are the result of mutations in genes required during development of specific leukocytes, i.e. T, B and/or NK cells. Until recently, allogeneic hematopoietic stem cell transplantation (HSCT) was the only curative treatment option for PID patients. However, the outcome of HSCT in SCID depends on many factors including histocompatibility, conditioning regimen, manipulation of the graft, and T-cell depletion (Friedrich \& Honig, 2010). In addition, allogeneic HSCT is often complicated by severe side effects resulting from both the conditioning regimen and graft versus host disease (GvHD). In cases where a suitable donor is unavailable, gene therapy offers the advantage of using the patient's own cells (autologous), thus preventing the immunologic complications related to GvHD. Moreover, the selective growth advantage of the genetically modified immune competent cells allows for minimal or no conditioning (EBMT/ESID guidelines for haematopoietic stem cell transplantation for primary immunodeficiencies 2017). Recent clinical trials using gene therapy have led to (partial) immune restoration in patients with X-linked SCID (X-SCID), adenosine deaminase (ADA)-deficient SCID, Wiskott-Aldrich syndrome (WAS) and chronic granulomatous disease (CGD).

The most common PID is X-linked SCID. The disease is the result of a mutation in the $I L 2 R G$ gene encoding the common gamma chain $(\gamma c)$ cytokine receptor subunit. This subunit is shared by the receptors for IL-2, IL-4, IL7, IL-9, IL-15 and IL-21. Abnormal signaling through these receptors results in disruption of the development of $\mathrm{T}$ - and NK-cells and B-cells, although present, cannot function properly due to the absence of T-cells. Between 1999 and 2006, 20 children for whom an HLA-compatible donor was not available, were treated in two gene therapy trials for X-SCID in Hôpital Necker, Paris (CavazzanaCalvo et al. 2000, Hacein-Bey-Abina et al. 2002) and Great Ormond Street Hospital (GOSH, London) (Gaspar et al. 2004). The vectors were based on the use of $\gamma \mathrm{RV}$ constructs in which the therapeutic gene, IL $2 R \gamma$, was placed under the transcriptional control of the LTR, with the use of either an amphotropic envelope (CavazzanaCalvo et al. 2000) or the gibbon ape leukemia virus (GALV) envelope (Gaspar et al. 2004). All children received ex vivo transduced $\mathrm{CD} 34+$ cells without preconditioning. Doses ranged from 5 to $20 \times 10^{6} \mathrm{CD} 34+$ $\gamma \mathrm{c}+$ cells $/ \mathrm{kg}$ weight. Between 31-68 months after infusion of the gene modified cells, 4 of the 10 patients from the Paris trial (Hacein-Bey-Abina et al. 2008) and 1 of the 10 patients in the London trial (Howe et al. 2008) developed a T-cell lymphoproliferative disorder. In the Paris trial, 2 patients had blast cells with activating vector insertions near the LIM domain-only 2 (LMO2) protooncogene (Hacein-Bey-Abina et al. 2003), 1 patient had blast cells with an integrated vector near LMO2 and a second integrated vector near the proto-oncogene $B M I 1$ and in the following patient, blast cells contained an integrated vector near a third proto-oncogene, CCND2 (Hacein-BeyAbina et al. 2008). The patient in the London trial developed T-ALL, and integration of the vector was found in an antisense orientation $35 \mathrm{~kb}$ upstream of $L M O 2$ (Howe et al. 2008). Although the role of LMO2 alone in oncogenesis has been shown in primary T-cell leukemia (Royer-Pokora et al. 1991) and hematopoietic tumors in mice (Dave et al. 2004), leukemogenesis in these patients was likely the result of overexpression of $L M O 2$, followed by the occurrence of other genetic abnormalities unrelated to vector insertion, including a gain-of-function mutation in NOTCH1, deletion of the tumor suppressor gene locus cyclin-dependent kinase $2 \mathrm{~A}(C D K N 2 A)$, and translocation of the TCR- $\beta$ region to the STIL-TAL1 locus (Hacein-BeyAbina et al. 2008, Howe et al. 2008). Chemotherapy led to sustained remission in 4 of the 5 patients and was associated with restoration of polyclonal gene-corrected $\mathrm{T}$-cell populations with a fully diverse $\mathrm{T}$-cell repertoire. 
The remaining subject passed away from refractory leukemia despite chemotherapy. As a result, a total of 19 out of 20 patients benefited from the therapeutic gene transfer (Hacein-Bey-Abina et al. 2008, Howe et al. 2008) and up to 10 years later, 17 were alive and maintained (nearly) full correction of the T-cell immunodeficiency (Cavazzana-Calvo et al. 2000, Hacein-Bey-Abina et al. 2002, Howe et al. 2008). Gene therapy at NIH in 3 children from 10 to 14 years of age, receiving up to $30 \times 10^{6} \mathrm{CD} 34+\gamma \mathrm{c}+$ cells $/ \mathrm{kg}$ was moderately successful (Chinen et al. 2007), whereas treatment of two older patients (20 years old) and receiving $0.8 \times 10^{6}$ and $4.5 \times 10^{6}$ $\mathrm{CD} 34+\gamma \mathrm{c}+$ cells $/ \mathrm{kg}$, respectively, completely failed to produce lasting recovery of T-cell immunity (Thrasher $e t$ al. 2005). Increasing age, as well as a clinical history of chronic infection and GvHD negatively affect the chances of the gene transfer treatment to restore effective thymopoiesis. In addition, thymus hypoplasia as a result of prolonged absence of interaction between $\mathrm{T}$-precursor cells and thymic epithelium can become irreversible. Therefore, it is strongly recommended that gene therapy in eligible SCID patients should be done as soon as possible after diagnosis (Aiuti \& Roncarolo 2009).

Adenosine deaminase (ADA) is an essential enzyme of the purine metabolism, which catalyzes the deamination of adenosine and deoxyadenosine in the purine catabolic pathway after DNA breakdown and is expressed in all tissues of the body (Blackburn \& Kellems 2005). ADA deficiency is a fatal, autosomal recessive disease and results in the intracellular accumulation of its metabolic substrates, dAXP and adenosine, causing toxicity not only in lymphoid progenitor cells, but also in bone, brain, lungs, liver and epithelia. The condition is particularly severe as the development of T, B and NKcells is affected, resulting in defects in both cell-mediated and humoral immunity (Blackburn \& Kellems 2005). The disease can be treated by HLA-identical HSCT (Antoine et al. 2003), with current survival rates up to $90 \%$ if treated at an early time point (Gaspar et al. 2009), but the use of alternative donors, such as matched unrelated donors (MUD) or umbilical cord blood (UCB), is associated with a high risk of (treatment-related) death or lack of engraftment (Gaspar 2010). Alternatively, enzyme replacement therapy (ERT) with Poly-ethylene glycolmodified ADA (Peg-ADA) can be started (Hershfield 1995). However, comparison of HSCT and ERT showed that where HSCT results in a constant peripheral T-cell number and diversification of the $\mathrm{T}$-cell repertoire and an increase in B-cells, ERT results in a slowly progressive narrowing of the $\mathrm{T}$-cell repertoire and a decrease in CD19+ lymphocytes in comparison to age-matched children (Serana et al. 2010). Initially, ADA-SCID patients were treated with retrovirally transduced peripheral blood lymphocytes (PBL) or autologous UCB (Kohn et al. 1998). Most patients displayed long-term persistence of transduced T-cells in the circulation, in the absence of toxicity, but due to low efficiency of gene transfer and engraftment, correction of the immunologic and metabolic defects was insufficient and all patients continued to receive ERT (Aiuti et al. 2002, Blaese et al. 1995, Bordignon et al. 1995, Kohn et al. 1998). Subsequently, more than 30 ADA-SCID patients have been treated with gene therapy in different transplantion centers worldwide (Cappelli \& Aiuti 2010, Ferrua et al. 2010a). 15 patients were treated with retrovirally transduced autologous HSC in HSR-TIGET, Italy (Aiuti et al. 2009, Aiuti \& Roncarolo, 2009, Aiuti et al. 2002), 10 in CHLA-NIH, USA (Engel et al. 2007, Sokolic et al. 2008), 5 in GOSH, UK (Gaspar et al. 2009, Gaspar et al. 2006), and 2 in Hokkaido, Japan (Otsu et al. 2006). The patients from the Italy trial displayed progressive immune reconstitution and long-term multilineage engraftment and were able to discontinue ERT treatment in 13 of the 15 cases (Aiuti \& Roncarolo 2009). In contrast to the gene therapy trials for X-SCID, no cases of leukemia related to insertional mutagenesis have been reported in patients treated for ADA-SCID (Aiuti et al. 2007), despite the use of a similar $\gamma \mathrm{RV}$ vector and the observation of a similar frequency of integration near LMO2 and other protooncogenes (Aiuti et al. 2007). These differences have been attributed to the use of different internal promoters and the transgene itself. These positive results have resulted in the approvement of Strimvelis, the first gene therapy drug for treatment of children with ADA-SCID, in 2016 by the European Commission (Aiuti et al. 2017, European Medicines Agency 2016).

$\mathrm{X}$-linked CGD is an inherited primary immunodeficiency disease, due to a defect in the gp91phox gene that encodes a NADPH oxidase transmembrane protein. CGD affects phagocytes resulting in defective intracellular killing (Kang et al. 2011), causing recurrent bacterial and fungal infections. The first gene therapy trials for CGD took place at the NIH in the 1990s using $\gamma \mathrm{RV}$ vectors (Malech et al. 1997). However, these gene therapy trials failed to sustain long-term engraftment of the retrovirally transduced CD34+ cells (Grez et al. 2011). In order to improve engraftment of transduced CD34+ cells, low dose non-myeloablative conditioning was used in following studies in two adults and two children. This resulted in improved engraftment and temporary clinical benefit. However, due to insertional activation of the proto-oncogene MDS1-EVII and transgene silencing, this clinical benefit was eventually lost and all patients developed myelodysplastic syndrome (MDS) (Ott et al. 2006, Siler et al. 2015, Stein et al. 2010). In total, 5 clinical trials were performed using $\gamma \mathrm{RV}$ vectors and cell engraftment progressively decreased with time in all 12 patients, with several patients developing MDS. In contrast to the gene therapy of other immune deficiencies, corrected HSCs did not appear to have a selective growth advantage. Furthermore, it has been suggested that the constitutive expression of gp91phox in HSCs may have led to overproduction of ROS, causing cellular toxicity and loss of the genetically corrected stem cells over time (Arnold \& Heimall 2017). Current gene therapy trials for CGD make use of codonoptimized third generation SIN-LV vectors to decrease the risk for insertional mutagenesis (Keller et al. 2018), 
and specific internal promoters designed to allow transgene expression restricted to the myeloid lineage only using a chimeric promoter (Santilli et al. 2011) or a myeloid specific promoter (Chiriaco et al. 2014).

Wiskott-Aldrich Syndrome (WAS) is a disorder caused by a mutation in the WAS gene that encodes WASp, a regulator protein of the main actin cytoskeleton and resulting in eczema, microtrombopenia, infections and autoimmunity in patients. In the first clinical trial for WAS a $\gamma \mathrm{RV}$ vector was used, which resulted in correction of the functional defect. However, 7 of the 9 treated patients developed leukemia, because of integrations in the LMO2, MDS1/EVI1, MN1 proto-oncogenes (Ghosh \& Gaspar 2017). The use of a SIN-LV-WASp vector to treat an adult WAS patient and 10 children showed promising results with rapid engraftment and sustained clinical improvement in the absence of insertional mutagenesis, showing that LV-based gene therapy may be developed as an alternative treatment for WAS (Hacein-Bey Abina et al. 2015, Morris et al. 2017).

\section{Hemoglobinopathies}

$\beta$-Thalassemia ( $\beta$-Thal) and Sickle Cell Disease (SCD) are the most common inherited monogenic disorders throughout the world, with more than 300,000 affected neonates born annually. Hemoglobinopathies are particularly common in Asian and Mediterranean countries, one of which is Turkey (Higgs et al. 2012). Especially, the incidence of $\beta$-Thal in the Marmara region (up to $11.7 \%$ ) and southern parts (up to $13.1 \%$ ), and SCD (up to $47 \%$ ) in Çukurova region of Turkey are very high (Kilinc 2006). According to a survey conducted by the Ministry of Health and hemoglobinopathy council in 2006, $5000 \beta$-Thal cases have been reported in Turkey, whereas the prevalence of SCD in Turkey is estimated to be $0.03-0.06 \%$. Both $\beta$ Thal and SCD are recessively inherited hemoglinopathies characterized by a mutation in the hemoglobin $\beta$ (HBB) gene. In SCD, a point mutation results in the formation of hemoglobin $\mathrm{S}(\mathrm{HbS})$, which polymerizes in the deoxygenated state, resulting in red blood cell sickling. Most patients suffer from chronic hemolytic anemia, acute and chronic pain, pulmonary and renal failure, cardiovascular disease and a cognitive decline. $\beta$-Thal results in reduced or abrogated $\beta$ hemoglobin production and ineffective erythropoiesis. Thalassemia major patients are transfusion dependent and suffer from severe hemolytic anemia, iron overload, hepatosplenomegaly, cardiomyopathy, endocrine disorders and skeletal abnormalities due to bone marrow expansion. The only current treatment of hemoglinopathies is allogenic HSCT from an HLAmatched donor. Genetic correction of autologous HSCs could serve as an alternative treatment option for hemoglinopathies in the absence of a suitable donor.

In order to increase the safety profile of LV vectors and improve expression of the $\mathrm{Hb}$ transgene, Puthenveetil et al. (2004) designed a $1.2 \mathrm{~kb}$ cHS4 insulator sequence, which blocks enhancer activity, preventing activation of nearby oncogenes, and reduces silencing of the transgene by heterochromatin. Further modifications of this insulator were used in following trials. In 2007, a single patient was infused with autologous CD34+ HSCs transduced with the HPV569 SIN-LV vector containing two copies of the cHS4 chromatin insulator in the U3 region and encoding a mutated adult $\beta$-globin $\left(\beta^{\mathrm{A}(\mathrm{T} 87 \mathrm{Q})}\right)$ with anti-sickling properties (Cavazzana-Calvo et al. 2010, Negre et al. 2015,). Three years after transplantation, the patient was tranfusion independent with a stable level of 8-9 g/dL Hb. A subsequent trial used an optimized version of the LV construct (Negre et al. 2015 ), without the cHS4 insulator and included a total of 18 patients with $\beta$-Thal and 4 patients with SCD BB305. All patients $(n=22)$ showed a highly polyclonal integration profile, with no clonal dominance, had stable $\mathrm{Hb}$ levels and became transfusion-indepent within 12 months after GT $(n=15)$ or required significantly less red blood cell transfusions ( $\mathrm{n}=7)$ (Cavazzana 2016, Thompson et al. 2016). The gene therapy trial resulted in stable hematopoetic reconstitution, was well tolerated and did not cause severe adverse events. A clinical trial in 2012 in four patients using the wild-type $\beta$-globin transgene resulted in limited gene transfer and lack of efficacy (Mansilla-Soto et al. 2016). In 2015, a clinical trial phase I/II was started in Italy for transfusion dependent patients. HSCs were transduced with the GLOBE SIN-LV vector, which expresses the wild-type $\beta$ globin transgene under the control of the $\beta$-globin promoter (Miccio et al. 2008, Roselli et al. 2010). In 2017, seven patients (3 adults and 4 children) with different genotypes had been enrolled and were treated with GLOBE-SIN-LV transduced $\mathrm{CD} 34^{+}$cells at a dose of $16 \times 10^{6}-19.5 \times 10^{6}$ cells $/ \mathrm{kg}$ (Marktel et al. 2017). The median follow-up was 13 months. The procedure was generally well tolerated by all patients, with no productrelated adverse events, no evidence of RCL or abnormal clonal proliferation (Marktel et al. 2017). Patients showed polyclonal multilineage engraftment, and three of the four treated children became transfusion independent, whereas transfusion requirements decreased in adults, indicating that age of treatment may be an important factor determining the efficacy of the procedure.

Preclinical studies for gene therapy of SCD demonstrated that gene therapy improved sickling. One patient in France was treated with BB305 lentiviral vector transduced HSCs. The patient was followed during two years and became transfusion independent with stable $\mathrm{Hb}$ levels of $12 \mathrm{~g} / \mathrm{dL}$ with therapeutic $\mathrm{Hb}$ and $\mathrm{HbS}$ accounting for $48 \%$ and $46 \%$ of the $\mathrm{Hb}$ tetramers, respectively (Ribeil et al. 2017). In an extended clinical phase I/II trial using this vector, peripheral blood levels of the BB305 vector remained low in all treated SCD subjects, with no evidence of clinical benefit (Kanter et al. 2016). In another two gene therapy clinical trials, an anti-sickling $\gamma / \beta$-globin transgene (sGbG) (Perumbeti et al. 2009) and a $\beta$-globin transgene with three anti-sickling point mutations (Lenti-bAS3-FB) (Romero et al. 2013) are being assessed currently. 


\section{Metabolic Disorders}

Adrenoleukodystrophy (ALD) is an X-linked disease caused by a defect in the ABCD1 (ATP-binding cassette subfamily D) gene which encodes the transporter of the ALD protein (ALDP). ALD was first described in 1992. ALD triggers accumulation of fatty acids that damage the myelin sheaths of neurons, causing motor and cognitive impairment. Allogeneic HSCT is the treatment of choice if a suitable donor is available (Shapiro et al. 2000). Lentiviral gene therapy is currently being developed based on promising results showing ALDP expressing human microglia in the brains of NOD/SCID mice after xenotransplantation of lentivirally transduced ALDP expressing human CD34+ HSCs (Benhamida et al. 2003). Preliminary results from HSC gene therapy indicated that a limited number of microglia cells may need to be corrected to prevent the demyelinating process (Cartier \& Aubourg 2010, Cartier et al. 2009). Autologous CD34+ cells genetically corrected using a lentiviral vector encoding the wild-type ABCD1 gene were reinfused into two boys with progressive cerebral demyelination. The boys displayed polyclonal, multilineage engraftment and no evidence of clonal dominance. Cerebral demyelination was arrested at 14 and 16 months, respectively, without further progression (Cartier et al. 2012, Cartier et al. 2009). In a subsequent phase II/III safety and efficacy clinical study, 17 boys with cerebral $\mathrm{X}$-ALD with early-stage disease and gadolinium enhancement on magnetic resonance imaging (MRI) were infused with autologous CD34+ cells transduced with the elivaldogene tavalentivec (Lenti-D) lentiviral vector. After 29 months of follow-up, all patients had multilineage engraftment of genetically modified cells, with no evidence of preferential integration near known oncogenes or clonal expansion. Although 2 of these 17 patients showed disease progression, the remaining 15 patients had stable expression of the ALD protein (Eichler et al. 2017).

Metachromic Leukodystrophy (MLD) is a neurodegenerative lysosomal storage disorder caused by arylsulfatase A (ARSA) deficiency and is autosomal recessively inherited. ARSA deficiency causes accumulation of sulphatide in the CNS, kidney, peripheral nerves, pancreas and liver. The disease affects children and results in premature deaths. Due to their cerebral involvement, both HSCT and development of ERT have been shown to be of limited success (Biffi et al. 2011, Boelens, 2006, Boelens et al. 2010, Rovelli \& Steward 2005). In previous studies, expression of ARSA was detected after transplantation of LV corrected HSCs in a MLD mouse model (Biffi et al. 2004, Biffi et al. 2006). Recently, a phase I/II clinical trial of MLD was performed in Italy. Three children with ARSA deficiency and mutations associated with early-onset MLD were treated at the presymptomatic stage and received autologous HSCs transduced with a lentivirus carrying the ARSA gene. All three patients showed high-level polyclonal, multilineage engraftment of the transduced HSCs and high ARSA activity was detected in the hematopoietic lineages and in the cerebrospinal fluid resulting in arrested progression of neurodegenerative symptoms (Biffi et al. 2013). No evidence of clonal expansion was detected, indicating that gene therapy may be a good alternative to HSCT, especially since the effects of ERT for storage diseases with cerebral brain involvement are limited.

For diseases such as Gaucher, Fabry and Pompe disease, ERT is available and effective. However, the development of gene therapy may still serve a purpose because of the impact on the patient (requiring recurrent visits to the hospital for ERT infusion), the costeffectiveness of the procedure (ERT is relatively expensive in comparison to a single gene therapy treatment) and because gene therapy of autologous HSCs is in intention a single, curative treatment and minimally invasive, increasing the quality of life of patients.

For other metabolic diseases for which allogeneic HSCT is possible, in the absence of a matched donor, gene therapy offers the advantages of decreasing morbidity related with allogeneic HSCT such as myeloablative conditioning and GvHD. Ongoing developments have made the used lentiviral vectors increasingly safe and promising results are obtained in clinical trials in most of the inherited monogenic diseases. An overview of the results of gene therapy trials for diseases discussed above is given in Table 2 .

New developments for improved lentiviral vector biosafety and efficacy

Gamma retroviral vectors have been shown to preferentially integrate near transcriptional start sites and regulatory gene regions of specific proto-oncogenes, such as LMO-2, CCND2, MDSI/EVI1, PRDM16, SETBP1, MECOM (Howe et al. 2008) and many of the initial clinical trials for X-linked SCID, CGD and WAS have shown the risks related to the use of $\gamma \mathrm{RV}$ (Ghosh \& Gaspar 2017, Hacein-Bey-Abina et al. 2008, Howe et al. 2008, Ott et al. 2006). To reduce the risks of insertional mutagenesis, third generation self-inactivating retroviral and lentiviral vectors were developed (Maetzig et al. 2011), which have been shown to have a signficantly improved safety profile (Bordignon et al. 1995, Cartier et al. 2012, Cartier et al. 2009, Cavazzana 2016, Hacein-Bey Abina et al. 2015, Kohn et al. 1998, Morris et al. 2017, Thompson et al. 2016).

Although the SIN-LV vectors, which display a preferred integration in transcribed genes, are considered less genotoxic than the SIN- $\gamma \mathrm{RV}$ vectors, the risks of insertional transformation of HSCs by both SIN$\mathrm{LV}$ and SIN- $\gamma \mathrm{RV}$ vectors remains present and appears to be dictated largely by the type of internal promoter used and the transgene itself (Modlich et al. 2009). Physiological (internal) promoters are generally weaker insertional mutagens in comparison to retroviral promoters (Zychlinski et al. 2008) and using lineage or tissue-specific promoters can therefore potentially increase biosafety (Pauwels et al. 2009). Furthermore, 
the use of tissue-specific promoters or inducible promoters over constitutively active promoters may result in a more physiological expression pattern of the transgene, which may be preferred to avoid cellular toxicity related to overexpression of transgenic proteins (Arnold \& Heimall 2017), as well as to avoid an immunological response against the transgenic protein. In vitro quantitative assays, such as immortalization tests, demonstrated that the risk of insertional activation of proto-oncogenes is directly related to the strength of the enhancer sequences contained in the vector (Schambach et al. 2013). One way to overcome this problem is to introduce insulators, such as cHS4, which can establish bounderies between regulatory sequences, into the viral genome (Gaszner \& Felsenfeld 2006,
Puthenveetil et al. 2004), both preventing activation of nearby proto-oncogenes and at the same time protecting the transgene from silencing by spreading heterochromatin. The design of novel pseudotypes may further increase cell-specific targeting during transduction of mixed populations of unstimulated hematopoietic stem and progenitor cells, which will improve transduction efficiency (Frecha et al. 2008). In addition, current developments with regards to direct targeting of viral integration into "safe sites" of the genome (gene addition) or targeted integration into the site of the mutated gene (gene replacement) using zinc finger nucleases (Porteus \& Carroll 2005) or CRISPRCas9 nucleases will greatly improve physiological regulation of the transgenic gene and biosafety.

Table 2. Results from clinical trials of hematopoietic stem cell gene therapy for inherited monogenic diseases.

\begin{tabular}{|c|c|c|c|c|c|c|c|}
\hline Disease & Phenotype & $\begin{array}{l}\text { Affected } \\
\text { gene }\end{array}$ & Vector & $\begin{array}{l}\text { Current } \\
\operatorname{Rx}\end{array}$ & Side effects & Clinical benefit & References \\
\hline X-SCID & $\begin{array}{l}\text { Absence of T and NK } \\
\text { cells and mature B cells }\end{array}$ & $\mathrm{IL} 2 \mathrm{R} \gamma$ & $\gamma \mathrm{RV}$ & HSCTx & $\begin{array}{l}\text { Insertional } \\
\text { mutagenesis }\end{array}$ & $\begin{array}{l}\text { Selective growth } \\
\text { advantage of transduced } \\
\text { cells } \\
\text { Immunological } \\
\text { reconstitution }\end{array}$ & $\begin{array}{l}\text { (Cavazzana-Calvo et al. } \\
\text { 2000, Hacein-Bey-Abina et } \\
\text { al. 2008, Hacein-Bey- } \\
\text { Abina et al. 2002, Howe et } \\
\text { al. 2008) }\end{array}$ \\
\hline $\begin{array}{l}\text { ADA- } \\
\text { SCID }\end{array}$ & $\begin{array}{l}\text { Immunodeficiency } \\
\text { neurological } \\
\text { abnormalities }\end{array}$ & $\mathrm{ADA}$ & $\gamma \mathrm{RV}$ & $\begin{array}{l}\text { ERT } \\
\text { HSCTx }\end{array}$ & - & $\begin{array}{l}\text { Selective growth } \\
\text { advantage of transduced } \\
\text { cells, } \\
\text { immunological } \\
\text { reconstitution, clinical } \\
\text { improvement, } \\
\text { discontinuation of ERT } \\
\text { treatment }\end{array}$ & $\begin{array}{l}\text { (Aiuti et al. 2007, Aiuti \& } \\
\text { Roncarolo 2009, Cappelli } \\
\text { \& Aiuti 2010, Ferrua et al. } \\
\text { 2010b) }\end{array}$ \\
\hline X-CGD & $\begin{array}{l}\text { Non-functional } \\
\text { phagocytes }\end{array}$ & Gp91phox & SIN-LV & HSCTx & $\begin{array}{l}\text { Insertional } \\
\text { mutagenesis }\end{array}$ & $\begin{array}{l}\text { No selective growth } \\
\text { advantage of transduced } \\
\text { cells } \\
\text { Cellular toxicity, loss of } \\
\text { corrected HSCs }\end{array}$ & $\begin{array}{l}\text { (Keller et al. 2018, Stein et } \\
\text { al. 2010) }\end{array}$ \\
\hline \multirow[t]{2}{*}{ WAS } & $\begin{array}{l}\text { Microthrombocytopenia, } \\
\text { autoimmunity }\end{array}$ & WASP & $\gamma \mathrm{RV}$ & HSCTx & $\begin{array}{l}\text { Insertional } \\
\text { mutagenesis }\end{array}$ & - & (Ghosh \& Gaspar 2017) \\
\hline & & & SIN-LV & & - & $\begin{array}{l}\text { Multilineage engraftment, } \\
\text { clinical improvement, no } \\
\text { clonal expansion }\end{array}$ & $\begin{array}{l}\text { (Hacein-Bey Abina et al. } \\
\text { 2015, Morris et al. 2017) }\end{array}$ \\
\hline$\beta$-Thal & Hemolytic Anemia & $\beta$-globin & SIN-LV & HSCTx & - & $\begin{array}{l}\text { Polyclonal integration, no } \\
\text { clonal dominance, } \\
\text { multilineage engraftment, } \\
\text { transfusion indepence }\end{array}$ & $\begin{array}{l}\text { (Cavazzana-Calvo et al. } \\
\text { 2010, Cavazzana 2016, } \\
\text { Thompson et al. 2016) }\end{array}$ \\
\hline SCD & Hemolytic anemia & $\beta$-globin & SIN-LV & HSCTx & - & Minimal clinical benefit & (Marktel et al. 2017) \\
\hline $\mathbf{X - A L D}$ & Cerebral demyelination & ABCD1 & SIN-LV & - & - & $\begin{array}{l}\text { Arrested progression of } \\
\text { demyelination, } \\
\text { polyclonal, multilineage } \\
\text { engraftment and no clonal } \\
\text { dominance }\end{array}$ & $\begin{array}{l}\text { (Cartier et al. 2012, Cartier } \\
\text { et al. 2009, Eichler } \text { et al. } \\
\text { 2017, Kohn et al. 1998) }\end{array}$ \\
\hline MLD & Cerebral demyelination & ARSA & SIN-LV & HSCTx & - & $\begin{array}{l}\text { High-level polyclonal, } \\
\text { multilineage engraftment, } \\
\text { arrested progression of } \\
\text { neurodegenerative } \\
\text { symptoms, no clonal } \\
\text { expansion }\end{array}$ & $\begin{array}{l}\text { (Biffi et al. 2013, } \\
\text { Bordignon et al. 1995) }\end{array}$ \\
\hline
\end{tabular}




\section{Current status of gene therapy research in Turkey}

Very few research groups in Turkey are currently working on the development of gene therapeutical approaches for inherited diseases. According to the website of the Scientific and Technological Research Council of Turkey (TÜBITAK, https://www.tubitak.gov.tr) genetic modification related R\&D activities were concentrated in projects in the Genetic Engineering and Biotechnologies Institute of MAM (Marmara Research Center). These projects however, were more focused on the development of different transgenic mouse models, development of vaccines or development of non-viral vectors. Search queries for research projects using "lentiviral" and "vector" as search items using the TÜBİTAK database for supported projects (www.cabim.ulakbilim.gov.tr/trdizin/tubitak-destekli-projeler-veritaban1) resulted in a total of 60 hits, of which only 1 focused on gene therapy. However, since this database has not been updated since 2013, these numbers are most likely not representative for the actual numbers of currently ongoing gene therapy related projects.

Why is the development of gene therapy important for Turkey?

Consanginous marriages increase the risk of autosomally inherited diseases. The highest rates of consanginous marriages occur in North and sub-Saharan Africa, the Middle East, and West, Central and South Asia. According to the Turkish statistical institute stastistic (TÜIK), the rate of consanginous marriage rates in Turkey is approximately $21 \%$. Of these, $35 \%$ are located in rural areas and $20-25 \%$ are located in urban areas. Within Turkey, the rates of consanginous marriages are highest in Southeastern Anatolia (40.4\%) and lowest in Western Marmara (4.8\%). Overall in Turkey, one in five marriages is between closely related family members, of which $70 \%$ between first cousins. Marriages between first and second cousins increases the risk of post-natal infant mortality significantly, with 45.9/1000 infant deaths in unrelated marriages, versus 72.1 infant deaths in consanguineous marriages (Sağlık Bakanlığı, 2002). This high level of consanguinity in Turkey results in a relatively high prevalence of PIDs and metabolic diseases in comparison to Europe and the USA and anually 4000 patients with possible PIDs are reffered to the 10 pediatric immunology centers in Turkey. In addition, according to an official publication by the Ministry of Health in 1996, the number of patients with diseases of blood or bloodforming organs, excluding anemias, reached 9597 within the years 1964-1994. Thus, the social economic burden of the not so rare diseases in Turkey is quite substantial.

For some of the inherited monogenic diseases allogeneic HSCT can be curative, and where outside of Turkey the search for an available, suitable donor may be difficult; in Turkey often matching donors can be found within families (Balci et al. 2011). However, even if available, both HSCT and ERT-related morbidity and frequent hospital visits, make the development of a single, curative treatment a tempting alternative. In addition, the costs related to HSCT, including conditioning and followup, and life-long treatment with ERT are considerable: In the USA, costs related to life-long ERT treatment for Fabry disease (Fabrazyme) are estimated to be \$200,000/year per patient; Hurler Syndrome (Aldurazyme) \$200,000/year per patient; Gaucher type 3 (Cerezyme) \$200.000/year per patient; Pompe disease (Myozyme) \$300.000/year per patient; Hunter Syndrome (Elaprase) \$375.000/year per patient. Whereas the national health insurance systems in West Europe fully reimburse costs related to HSCT or ERT, other countries may not or not completely cover costs related to orphan drugs (Shah 2006), making the development of a single, curative treatment, such as gene therapy for these countries a high priority.

\section{Recommendations for Turkey}

The rationale of gene therapy is to repair, inactivate or to replace dysfunctional genes that cause disease with the aim of establishing or acquiring normal function. Hematopoietic stem cell gene therapy offers a possible curative treatment option for a range of patients with inherited monogenic diseases, who currently have no alternative treatment option, such as HSCT or ERT. Many gene therapy clinical trials have been performed mostly in Europe and the USA during the last twenty years for a wide range of immune deficiencies and metabolic diseases, of which only a fraction is discussed above. Although several Turkish patients have been treated with gene therapy for ADA-SCID, CGD and WAS, and patients enrolled in gene therapy clinical trials include a disproportionate number of children from Turkish origin, development of gene therapy or participation in gene therapy clinical trials for inherited monogenic diseases in Turkey is not currently actively pursued.

Gene therapy not only offers a curative treatment option, but also, as observed with the latest SIN-LV contructs, provides in general a good quality of life, low treatment-related morbidity, a decreased duration and frequency of hospitalization in addition to an improved clinical condition. However, the efficacy of the treatment is not only related to the number of cells infused, the vector copy number per cell or the level of transgene expression, but even more to the general condition of the patient upon start of the treatment. When gene therapy is done in eligible patients as soon as possible after diagnosis and preferably before irreversible symptoms occur, these patients have the best chances of good recovery and clinical improvement (Aiuti \& Roncarolo 2009, Bordignon et al. 1995, Marktel et al. 2017, Thrasher et al. 2005)

Although current lentiviral vectors still harbor the intrinsic risk of insertional mutagenesis, recent clinical trials have shown that the actual occurrence of myelodysplastic syndromes and leukemogenesis is very low and that the benefits of the treatment outweigh the risks. Obviously, the long-term risks of the procedures cannot be fully appreciated, since gene therapy is just 
coming of age, and assessment of these risks will require carefully planned, long-term follow-up of all treated patients. However, future improvements resulting in tissue-specific expression of genes, replacement of genes rather than addition, and increased biosafety will make hematopoietic stem cell gene therapy a powerful new tool to cure previously incurable patients. Therefore, the establishment of specialized centers in Turkey for gene therapy research, for the development of clinical gene therapy or participation in phase I/II gene therapy studies and for the production and quality control of gene therapy products should be stimulated.

In conclusion, lentiviral treatment of rare, inherited diseases is being rapidly developed and optimized and

\section{References}

1. Aiuti, A., Cassani, B., Andolfi, G., Mirolo, M., Biasco, L., Recchia, A, Urbinati, F., Valacca, C., Scaramuzza, S., Aker, M., Slavin, S., Cazzola, M., Sartori, D., Ambrosi, A., Di Serio, C., Roncarolo, M.G., Mavilio, F. \& Bordignon, C. 2007. Multilineage hematopoietic reconstitution without clonal selection in ADA-SCID patients treated with stem cell gene therapy. The Journal of Clinical Investigation, 117(8): 2233-40.

2. Aiuti, A., Cattaneo, F., Galimberti, S., Benninghoff, U., Cassani, B., Callegaro, L., Scaramuzza, S., Andolfi, G., Mirolo, M., Brigida, I., Tabucchi, A., Carlucci, F., Eibl, M., Aker, M., Slavin, S., Al-Mousa, H., Al Ghonaium, A., Ferster, A., Duppenthaler, A., Notarangelo, L., Wintergerst, U., Buckley, R.H., Bregni, M., Marktel, S., Valsecchi, M.G., Rossi, P., Ciceri, F., Miniero, R., Bordignon, C. \& Roncarolo, M.G. 2009. Gene therapy for immunodeficiency due to adenosine deaminase deficiency. New England Journal of Medicine, 360(5): 447-458.

3. Aiuti, A. \& Roncarolo, M.G. 2009. Ten years of gene therapy for primary immune deficiencies. Hematology of the American Society Hematology Education Program, 1: 682-689.

4. Aiuti, A., Roncarolo, M.G. \& Naldini, L. 2017. Gene therapy for Ada-scid, the first marketing approval of an: paving the road for the next generation of advanced therapy medicinal productsex vivo: paving the road for the next generation of advanced therapy medicinal products gene therapy in Europe: paving the road for the next generation of advanced therapy medicinal products. Embo Molecular Medicine, 9(6): 737-740.

5. Aiuti, A., Slavin, S., Aker, M., Ficara, F., Deola, S., Mortellaro, A., Morecki, S., Andolfi, G., Tabucchi, A., Carlucci, F., Marinello, E., Cattaneo, F., Vai, S., Servida, P., Miniero, R., Roncarolo, M.G. \& Bordignon, C. 2002. Correction of ADA-SCID by stem cell gene therapy combined with nonmyeloablative conditioning. Science, 296(5577): 2410-2413.

6. Aiuti, A., Vai, S., Mortellaro, A., Casorati, G., Ficara, F., Andolfi, G., Ferrari, G., Tabucchi, A., Carlucci, F., Ochs, H.D., Notarangelo, L.D., Roncarolo, M.G. \& Bordignon, C. 2002. Immune reconstitution in ADA-SCID after PBL gene therapy and discontinuation of enzyme replacement. Nature Medicine, 8(5): 423-425. currently tested in multicenter preclinical trials. Although past experiences with retroviral and lentiviral gene therapy have shown that results should be assessed carefully, and long-term follow-up remains required, current data are very promising. Therefore, we recommend development of a specialized research center infrastructure that would allow participation of Turkey not only by providing patients or patient samples, but also by taking part at the research level and in the preclinical trials.

\section{Acknowledgement}

This work was supported by a grant from the Scientific and Technological Research council of Turkey TÜBİTAK 2221, grant no 2017/2 to F.A.K.

7. Antoine, C., Muller, S., Cant, A., Cavazzana-Calvo, M., Veys, P., Vossen, J., Fasth, A., Heilmann, C., Wulffraat, N., Seger, R., Blanche, S., Friedrich, W., Abinun, M., Davies, G., Bredius, R., Schulz, A., Landais, P. $\&$ Fischer, A. 2003. Long-term survival and transplantation of haemopoietic stem cells for immunodeficiencies: report of the European experience 1968-99. Lancet, 361(9357): 553-560.

8. Arnold, D.E. \& Heimall, J.R. 2017. A Review of Chronic Granulomatous Disease. Advances in Therapy, 34(12): 2543-2557.

9. Balci, Y.I., Tavil, B., Tan, C.S., Ozgur, T.T., Bulum, B., Cetin, M., Balci, M., Yalcin, S., Tezcan, I. \& Uckan, D. 2011. Increased availability of family donors for hematopoietic stem cell transplantation in a population with increased incidence of consanguinity. Clinical Transplantation, 25(3): 475-480.

10. Banasik, M.B. \& McCray, P.B., Jr. 2010. Integrasedefective lentiviral vectors: progress and applications. Gene Therapy, 17(2):150-157.

11. Beck, M. 2018. Treatment strategies for lysosomal storage disorders. Developmental Medicine and Child Neurology, 60(1):13-18.

12. Benhamida, S., Pflumio, F., Dubart-Kupperschmitt, A., Zhao-Emonet, J.C., Cavazzana-Calvo, M., Rocchiccioli, F., Fichelson, S., Aubourg, P., Charneau, P. \& Cartier, N. 2003. Transduced CD34+ cells from adrenoleukodystrophy patients with HIV-derived vector mediate long-term engraftment of NOD/SCID mice. Molecular Therapy, 7(3): 317-324.

13. Berkhout, B. 2017. A Fourth Generation Lentiviral Vector: Simplifying Genomic Gymnastics. Molecular Therapy, 25(8): 1741-1743.

14. Biffi, A. 2017. Hematopoietic Stem Cell Gene Therapy for Storage Disease: Current and New Indications. Molecular Therapy, 25(5): 1155-1162.

15. Biffi, A., Aubourg, P. \& Cartier, N. 2011. Gene therapy for leukodystrophies. Human Molecular Genetics, 20(R1); R42-53.

16. Biffi, A., Capotondo, A., Fasano, S., del Carro, U., Marchesini, S., Azuma, H., Malaguti, M.C., Amadio, S., Brambilla, R., Grompe, M., Bordignon, C., Quattrini, 
A. \& Naldini, L. 2006. Gene therapy of metachromatic leukodystrophy reverses neurological damage and deficits in mice. The Journal of Clinical Investigation, 116(11): 3070-3082.

17. Biffi, A., De Palma, M., Quattrini, A., Del Carro, U., Amadio, S., Visigalli, I., Sessa, M., Fasano, S., Brambilla, R., Marchesini, S., Bordignon, C. \& Naldini, L. 2004. Correction of metachromatic leukodystrophy in the mouse model by transplantation of genetically modified hematopoietic stem cells. The Journal of Clinical Investigation, 113(8): 1118-1129.

18. Biffi, A., Montini, E., Lorioli, L., Cesani, M., Fumagalli, F., Plati, T., Baldoli, C., Martino, S., Calabria, A., Canale, S., Benedicenti, F., Vallanti, G., Biasco, L., Leo, S., Kabbara, N., Zanetti, G., Rizzo, W.B., Mehta, N.A., Cicalese, M.P., Casiraghi, M., Boelens, J.J., Del Carro, U., Dow, D.J., Schmidt, M., Assanelli, A., Neduva, V., Di Serio, C., Stupka, E., Gardner, J., von Kalle, C., Bordignon, C., Ciceri, F., Rovelli, A., Roncarolo, M.G., Aiuti, A., Sessa, M. \& Naldini, L. 2013. Lentiviral hematopoietic stem cell gene therapy benefits metachromatic leukodystrophy. Science, 341(6148): 1233158.

19. Blackburn, M.R. \& Kellems, R.E. 2005. Adenosine deaminase deficiency: metabolic basis of immune deficiency and pulmonary inflammation. Advances in Immunology, 86: 1-41.

20. Blaese, R.M., Culver, K.W., Miller, A.D., Carter, C.S., Fleisher, T., Clerici, M., Shearer, G., Chang, L., Chiang, Y., Tolstoshev, P., Greenblatt, J.J., Rosenberg, S.A., Klein, H., Berger, M., Mullen, C.A., Ramsey, W.J., Muul, L., Morgan, R.A. \& Anderson, W.F. 1995. T lymphocytedirected gene therapy for ADA- SCID: initial trial results after 4 years. Science, 270(5235): 475-480.

21. Boelens, J.J. 2006. Trends in haematopoietic cell transplantation for inborn errors of metabolism. Journal of Inherited Metabolic Disease, 29(2-3): 413-420.

22. Boelens, J.J., Prasad, V.K., Tolar, J., Wynn, R.F. \& Peters, C. 2010. Current international perspectives on hematopoietic stem cell transplantation for inherited metabolic disorders. Pediatric Clinics of North America, 57(1): 123-145.

23. Bordignon, C., Notarangelo, L.D., Nobili, N., Ferrari, G., Casorati, G., Panina, P., Mazzolari, E., Maggioni, D., Rossi, C., Servida, P., Ugazio, A.G. \& Mavilio, F. 1995. Gene therapy in peripheral blood lymphocytes and bone marrow for ADA- immunodeficient patients. Science, 270(5235): 470-475.

24. Buchschacher, G.L., Jr. \& Wong-Staal, F. 2000. Development of lentiviral vectors for gene therapy for human diseases. Blood, 95(8): 2499-2504.

25. Cappelli, B. \& Aiuti, A. 2010. Gene therapy for adenosine deaminase deficiency. Immunology and Allergy Clinics of North America, 30(2): 249-260.

26. Cartier, N. \& Aubourg, P. 2010. Hematopoietic stem cell transplantation and hematopoietic stem cell gene therapy in X-linked adrenoleukodystrophy. Brain Pathology, 20(4): 857-862.

27. Cartier, N., Hacein-Bey-Abina, S., Bartholomae, C.C., Bougneres, P., Schmidt, M., Kalle, C.V., Fischer,
A., Cavazzana-Calvo, M. \& Aubourg, P. 2012. Lentiviral hematopoietic cell gene therapy for X-linked adrenoleukodystrophy. Methods in Enzymology, 507: 187198.

28. Cartier, N., Hacein-Bey-Abina, S., Bartholomae, C.C., Veres, G., Schmidt, M., Kutschera, I., Vidaud, M., Abel, U., Dal-Cortivo, L., Caccavelli, L., Mahlaoui, N., Kiermer, V., Mittelstaedt, D., Bellesme, C., Lahlou, N., Lefrère, F., Blanche, S., Audit, M., Payen, E., Leboulch, P., l'Homme, B., Bougnères, P., Von Kalle, C., Fischer, A., Cavazzana-Calvo, M. \& Aubourg, P. 2009. Hematopoietic stem cell gene therapy with a lentiviral vector in X-linked adrenoleukodystrophy. Science, 326(5954): 818-823.

29. Cavazzana-Calvo, M., Hacein-Bey, S., de Saint Basile, G., Gross, F., Yvon, E., Nusbaum, P., Selz, F., Hue, C., Certain, S., Casanova, J.L., Bousso, P., Deist, F.L. \& Fischer, A. 2000. Gene therapy of human severe combined immunodeficiency (SCID)-X1 disease. Science, 288(5466): 669-672.

30. Cavazzana-Calvo, M., Payen, E., Negre, O., Wang, G., Hehir, K., Fusil, F., Down, J., Denaro, M., Brady, T., Westerman, K., Cavallesco, R., Gillet-Legrand, B., Caccavelli, L., Sgarra, R., Maouche-Chrétien, L., Bernaudin, F., Girot, R., Dorazio, R., Mulder, G.J., Polack, A., Bank, A., Soulier, J., Larghero, J., Kabbara, N., Dalle, B., Gourmel, B., Socie, G., Chrétien, S., Cartier, N., Aubourg, P., Fischer, A., Cornetta, K., Galacteros, F., Beuzard, Y., Gluckman, E., Bushman, F., Hacein-Bey-Abina, S. \& Leboulch, P. 2010. Transfusion independence and HMGA2 activation after gene therapy of human beta-thalassaemia. Nature, 467(7313): 318-322.

31. Cavazzana, M. 2016. Gene Therapy Studies in Hemoglobinopathies: Successes and Challenges. Blood, 128(22): SCI-50

32. Chinen, J., Davis, J., De Ravin, S.S., Hay, B.N., Hsu, A.P., Linton, G.F., Naumann, N., Nomicos, E.Y., Silvin, C., Ulrick, J., Whiting-Theobald, N.L., Malech, H.L. \& Puck, J.M. 2007. Gene therapy improves immune function in preadolescents with X-linked severe combined immunodeficiency. Blood, 110(1): 67-73.

33. Chiriaco, M., Farinelli, G., Capo, V., Zonari, E., Scaramuzza, S., Di Matteo, G., Sergi, L.S., Migliavacca, M., Hernandez, R.J., Bombelli, F., Giorda, E., KajasteRudnitski, A., Trono, D., Grez, M., Rossi, P., Finocchi, A., Naldini, L., Gentner, B. \& Aiuti, A. 2014. Dualregulated lentiviral vector for gene therapy of X-linked chronic granulomatosis. Molecular Therapy, 22(8): 14721483.

34. Commission Staff Working Document on the experience acquired as a result of the application of Regulation (EC) No 141/2000 on orphan medicinal products and account of the public health benefits obtained 2006 from http://ec.europa.eu/health/files/orphanmp/doc/orphan_en_ 06-2006_en.pdf (Date accessed: 12 September 2018)

35. Dave, U.P., Jenkins, N.A. \& Copeland, N.G. 2004. Gene therapy insertional mutagenesis insights. Science, 303(5656): 333.

36. Deichmann, A., Hacein-Bey-Abina, S., Schmidt, M., Garrigue, A., Brugman, M.H., Hu, J., Glimm, H., Gyapay, 
G., Prum, B., Fraser, C.C., Fischer, N., Schwarzwaelder, K., Siegler, M.L., de Ridder, D., Pike-Overzet, K., Howe, S.J., Thrasher, A.J., Wagemaker, G., Abel, U., Staal, F.J., Delabesse, E., Villeval, J.L., Aronow, B., Hue, C., Prinz, C., Wissler, M., Klanke, C., Weissenbach, J., Alexander, I., Fischer, A., von Kalle, C. \& CavazzanaCalvo, M. 2007. Vector integration is nonrandom and clustered and influences the fate of lymphopoiesis in SCID$\mathrm{X} 1$ gene therapy. The Journal of Clinical Investigation, 117(8): 2225-2232.

37. DiMasi, J.A., Hansen, R.W. \& Grabowski, H.G. 2003. The price of innovation: new estimates of drug development costs. Journal of Health Economics, 22(2): 151-185.

38. Dull, T., Zufferey, R., Kelly, M., Mandel, R.J., Nguyen, M., Trono, D. \& Naldini, L. 1998. A third-generation lentivirus vector with a conditional packaging system. Journal of Virology, 72(11): 8463-8471.

39. EBMT/ESID guidelines for haematopoietic stem celltransplantation for primary immunodeficiencies, 2017. EC No 141/2000. from http://eurlex.europa.eu/LexUriServ/LexUriServ.do?uri=OJ:L:2000: 018:0001:0005:en:PDF EC No 847/2000. from http://ec.europa.eu/health/files/eudralex/vol1/reg_2000_847/reg_2000_847_en.pdf

40. EC No 141/2000. from http://eurlex.europa.eu/LexUriServ/LexUriServ.do?uri=OJ:L:2000: 018:0001:0005:en:PDF

41. EC No 847/2000. from http://ec.europa.eu/health/files/eudralex/vol1/reg_2000_847/reg_2000_847_en.pdf

42. Eichler, F., Duncan, C., Musolino, P.L., Orchard, P.J., De Oliveira, S., Thrasher, A.J., Armant, M., Dansereau, C., Lund, T.C., Miller, W.P., Raymond, G.V., Sankar, R., Shah, A.J., Sevin, C., Gaspar, H.B., Gissen, P., Amartino, H., Bratkovic, D., Smith, N.J.C., Paker, A.M., Shamir, E., O'Meara, T., Davidson, D., Aubourg, P. \& Williams, D.A. 2017. Hematopoietic Stem-Cell Gene Therapy for Cerebral Adrenoleukodystrophy. The New England Journal of Medicine, 377(17): 1630-1638.

43. Engel, B.C., Podsakoff, G.M., Ireland, J.L., Smogorzewska, E.M., Carbonaro, D.A., Wilson, K., Shah, A., Kapoor, N., Sweeney, M., Borchert, M., Crooks, G.M., Weinberg, K.I., Parkman, R., Rosenblatt, H.M., Wu, S.Q., Hershfield, M.S., Candotti, F. \& Kohn, D.B. 2007. Prolonged pancytopenia in a gene therapy patient with ADA-deficient SCID and trisomy 8 mosaicism: a case report. Blood, 109(2): 503-506.

44. Ferrua, F., Brigida, I. \& Aiuti, A. 2010. Update on gene therapy for adenosine deaminase-deficient severe combined immunodeficiency. Current Opinion in Allergy and Clinical Immunology, 10(6): 551-556.

45. Frecha, C., Szecsi, J., Cosset, F.L. \& Verhoeyen, E. 2008. Strategies for targeting lentiviral vectors. Current Gene Therapy, 8(6): 449-460.

46. Friedrich, W. \& Honig, M. 2010. HLA-haploidentical donor transplantation in severe combined immunodeficiency. Immunology and Allergy Clinics of North America, 30(1): 31-44.

47. Gaspar, H.B. 2010. Bone marrow transplantation and alternatives for adenosine deaminase deficiency.
Immunology and Allergy Clinics of North America, 30(2): 221-236.

48. Gaspar, H.B., Aiuti, A., Porta, F., Candotti, F., Hershfield, M.S. \& Notarangelo, L.D. 2009. How I treat ADA deficiency. Blood, 114(17): 3524-3532.

49. Gaspar, H.B., Bjorkegren, E., Parsley, K., Gilmour, K.C., King, D., Sinclair, J., Zhang, F., Giannakopoulos, A., Adams, S., Fairbanks, L.D., Gaspar, J., Henderson, L., Xu-Bayford, J.H., Davies, E.G., Veys, P.A., Kinnon, C. \& Thrasher, A.J. 2006. Successful reconstitution of immunity in ADA-SCID by stem cell gene therapy following cessation of PEG-ADA and use of mild preconditioning. Molecular Therapy, 14(4): 505-513.

50. Gaspar, H.B., Parsley, K.L., Howe, S., King, D., Gilmour, K.C., Sinclair, J., Brouns, G., Schmidt, M., Von Kalle, C., Barington, T., Jakobsen, M.A., Christensen, H.O., Al Ghonaium, A., White, H.N., Smith, J.L., Levinsky, R.J., Ali, R.R., Kinnon, C. \& Thrasher, A.J. 2004. Gene therapy of X-linked severe combined immunodeficiency by use of a pseudotyped gammaretroviral vector. Lancet, 364(9452): 2181-2187.

51. Gaszner, M. \& Felsenfeld, G. 2006. Insulators: exploiting transcriptional and epigenetic mechanisms. Nature Reviews Genetics, 7(9): 703-713.

52. Sağlık Bakanlığı, 2002. Genetik Hastalıklar Sağllk Personeli İçin El Kitabı. Ana Çocuk Sağlığı ve Aile Planlaması Genel Müdürlüğü, No: 749, ISBN: 978-975590-273-9, Retrieved from https://sbu.saglik.gov.tr/Ekutuphane/Yayin/136.

53. Ghosh, S. \& Gaspar, H.B. 2017. Gene Therapy Approaches to Immunodeficiency. Hematology, Oncology Clinics of North America, 31(5): 823-834.

54. Grez, M., Reichenbach, J., Schwable, J., Seger, R., Dinauer, M.C. \& Thrasher, A. J. 2011. Gene therapy of chronic granulomatous disease: the engraftment dilemma. Molecular Therapy, 19(1): 28-35.

55. Hacein-Bey-Abina, S., Garrigue, A., Wang, G.P., Soulier, J., Lim, A., Morillon, E., Clappier, E., Caccavelli, L., Delabesse, E., Beldjord, K., Asnafi, V., MacIntyre, E., Dal Cortivo, L., Radford, I., Brousse, N., Sigaux, F., Moshous, D., Hauer, J., Borkhardt, A., Belohradsky, B.H., Wintergerst, U., Velez, M.C., Leiva, L., Sorensen, R., Wulffraat, N., Blanche, S., Bushman, F.D., Fischer, A. \& Cavazzana-Calvo, M. 2008. Insertional oncogenesis in 4 patients after retrovirus-mediated gene therapy of SCIDX1. The Journal of Clinical Investigation, 118(9): 31323142.

56. Hacein-Bey-Abina, S., Le Deist, F., Carlier, F., Bouneaud, C., Hue, C., De Villartay, J. P., Thrasher, A.J., Wulffraat, N., Sorensen, R., Dupuis-Girod, S., Fischer, A., Davies, E.G., Kuis, W., Leiva, L. \& Cavazzana-Calvo, M. 2002. Sustained correction of X-linked severe combined immunodeficiency by ex vivo gene therapy. The New England Journal of Medicine, 346(16): 1185-1193.

57. Hacein-Bey-Abina, S., Von Kalle, C., Schmidt, M., McCormack, M.P., Wulffraat, N., Leboulch, P., Lim, A., Osborne, C.S., Pawliuk, R., Morillon, E., Sorensen, R., Forster, A., Fraser, P., Cohen, J.I., de Saint Basile, G., Alexander, I., Wintergerst, U., Frebourg, T., Aurias, A., Stoppa-Lyonnet, D., Romana, S., Radford-Weiss, 
I., Gross, F., Valensi, F., Delabesse, E., Macintyre, E., Sigaux, F., Soulier, J., Leiva, L.E., Wissler, M., Prinz, C., Rabbitts, T.H., Le Deist, F., Fischer, A. \& CavazzanaCalvo, M. 2003. LMO2-associated clonal T cell proliferation in two patients after gene therapy for SCIDX1. Science, 302(5644): 415-419.

58. Hacein-Bey Abina, S., Gaspar, H.B., Blondeau, J., Caccavelli, L., Charrier, S., Buckland, K., Picard, C., Six, E., Himoudi, N., Gilmour, K., McNicol, A.M., Hara, H., Xu-Bayford, J., Rivat, C., Touzot, F., Mavilio, F., Lim, A., Treluyer, J.M., Héritier, S., Lefrère, F., Magalon, J., Pengue-Koyi, I., Honnet, G., Blanche, S., Sherman, E.A., Male, F., Berry, C., Malani, N., Bushman, F.D., Fischer, A., Thrasher, A.J., Galy, A. \& Cavazzana, M. 2015. Outcomes following gene therapy in patients with severe Wiskott-Aldrich syndrome. Journal of the American Medical Association, 313(15):1550-1563.

59. Hershfield, M.S. 1995. PEG-ADA replacement therapy for adenosine deaminase deficiency: an update after 8.5 years. Clinical Immunology and Immunopathology, 76(3 Pt 2): S228-232.

60. Higgs, D.R., Engel, J.D. \& Stamatoyannopoulos, G. 2012. Thalassaemia. Lancet, 379(9813): 373-383.

61. Howe, S.J., Mansour, M.R., Schwarzwaelder, K., Bartholomae, C., Hubank, M., Kempski, H., Brugman, M.H., Pike-Overzet, K., Chatters, S.J., de Ridder, D., Gilmour, K.C., Adams, S., Thornhill, S.I., Parsley, K.L., Staal, F.J., Gale, R.E., Linch, D.C., Bayford, J., Brown, L., Quaye, M., Kinnon, C., Ancliff, P., Webb, D.K., Schmidt, M., von Kalle, C., Gaspar, H.B. \& Thrasher, A.J. 2008. Insertional mutagenesis combined with acquired somatic mutations causes leukemogenesis following gene therapy of SCID-X1 patients. The Journal of Clinical Investigation, 118(9): 3143-3150.

62. Kang, H.J., Bartholomae, C C., Paruzynski, A., Arens, A., Kim, S., Yu, S.S., Hong, Y., Joo, C.W., Yoon, N.K., Rhim, J.W., Kim, J.G., Von Kalle, C., Schmidt, M., Kim, S. \& Ahn, H.S. 2011. Retroviral gene therapy for X-linked chronic granulomatous disease: results from phase I/II trial. Molecular Therapy, 19(11): 2092-2101.

63. Kanter, J., Walters, M.C., Hsieh, M.M., Krishnamurti, L., Kwiatkowski, J., Kamble, R. T., von Kalle, C., Kuypers, F. A., Cavazzana, M. \& Leboulch, P. 2016. Interim Results from a Phase 1/2 Clinical Study of Lentiglobin Gene Therapy for Severe Sickle Cell Disease. Blood, 128(22): 1176-1176.

64. Keller, M.D., Notarangelo, L.D. \& Malech, H.L. 2018. Future of Care for Patients With Chronic Granulomatous Disease: Gene Therapy and Targeted Molecular Medicine. Journal of the Pediatric Infectious Diseases Society, 7(suppl_1): 40-44.

65. Kilinc, Y. 2006. Hemoglobinopathies in Turkey. Turkish Journal of Hematology, 23(4): 214-216.

66. Kohn, D.B., Hershfield, M.S., Carbonaro, D., Shigeoka, A., Brooks, J., Smogorzewska, E. M., Barsky, L.W., Chan, R., Burotto, F., Annett, G., Nolta, J.A., Crooks, G., Kapoor, N., Elder, M., Wara, D., Bowen, T., Madsen, E., Snyder, F.F., Bastian, J., Muul, L., Blaese, R.M., Weinberg, K. \& Parkman, R.1998. T lymphocytes with a normal ADA gene accumulate after transplantation of transduced autologous umbilical cord blood CD34+ cells in ADA-deficient SCID neonates. Nature Medicine, 4(7): 775-780.

67. Lewis, P.F. \& Emerman, M. 1994. Passage through mitosis is required for oncoretroviruses but not for the human immunodeficiency virus. Journal of Virology, 68(1): 510516.

68. Maetzig, T., Galla, M., Baum, C. \& Schambach, A. 2011. Gammaretroviral vectors: biology, technology and application. Viruses, 3(6): 677-713.

69. Majhail, N.S., Farnia, S.H., Carpenter, P.A., Champlin, R.E., Crawford, S., Marks, D. I., Omel, J.L., Orchard, P.J., Palmer, J., Saber, W., Savani, B.N., Veys, P.A., Bredeson, C.N., Giralt, S.A. \& LeMaistre, C.F. 2015. Indications for Autologous and Allogeneic Hematopoietic Cell Transplantation: Guidelines from the American Society for Blood and Marrow Transplantation. Biology of Blood and Marrow Transplantation, 21(11): 1863-1869.

70. Malech, H.L., Maples, P.B., Whiting-Theobald, N., Linton, G.F., Sekhsaria, S., Vowells, S.J., Li, F., Miller, J.A., DeCarlo, E., Holland, S.M., Leitman, S.F., Carter, C.S., Butz, R.E., Read, E.J., Fleisher, T.A., Schneiderman, R.D., Van Epps, D.E., Spratt, S.K., Maack, C.A., Rokovich, J.A., Cohen, L.K. \& Gallin, J.I. 1997. Prolonged production of NADPH oxidase-corrected granulocytes after gene therapy of chronic granulomatous disease. Proceedings of the National Academy of Sciences of the United States of America, 94(22): 12133-12138.

71. Mansilla-Soto, J., Riviere, I., Boulad, F. \& Sadelain, M. 2016. Cell and Gene Therapy for the Beta-Thalassemias: Advances and Prospects. Human Gene Therapy, 27(4): 95304.

72. Marktel, S., Cicalese, M.P., Giglio, F., Scaramuzza, S., Calbi, V., Casiraghi, M., Ciotti, F., Lidonnici, M.R., Rossi, C. \& Masera, N. 2017. Gene Therapy for Beta Thalassemia: Preliminary Results from the PHASE I/II Tiget-Bthal Trial of Autologous Hematopoietic Stem Cells Genetically Modified with GLOBE Lentiviral Vector. Blood, 130(Suppl 1): 355-355.

73. Miccio, A., Cesari, R., Lotti, F., Rossi, C., Sanvito, F., Ponzoni, M., Routledge, S.J., Chow, C.M., Antoniou, M.N. \& Ferrari, G. 2008. In vivo selection of genetically modified erythroblastic progenitors leads to long-term correction of beta-thalassemia. Proceedings of the National Academy of Sciences of the United States of America, 105(30): 10547-10552.

74. Miyoshi, H., Smith, K.A., Mosier, D.E., Verma, I.M. \& Torbett, B.E. 1999. Transduction of human CD34+ cells that mediate long-term engraftment of NOD/SCID mice by HIV vectors. Science, 283(5402): 682-686.

75. Modlich, U., Navarro, S., Zychlinski, D., Maetzig, T., Knoess, S., Brugman, M. H., Schambach, A., Charrier, S., Galy, A., Thrasher, A.J., Bueren, J. \& Baum, C. 2009. Insertional transformation of hematopoietic cells by selfinactivating lentiviral and gammaretroviral vectors. Molecular Therapy, 17(11): 1919-1928.

76. Morris, E. C., Fox, T., Chakraverty, R., Tendeiro, R., Snell, K., Rivat, C., Grace, S., Gilmour, K., Workman, S., Buckland, K., Butler, K., Chee, R., Salama, A.D., Ibrahim, H., Hara, H., Duret, C., Mavilio, F., Male, F., Bushman, F.D., Galy, A., Burns, S.O., Gaspar H.B. 
\& Thrasher, A.J. 2017. Gene therapy for Wiskott-Aldrich syndrome in a severely affected adult. Blood, 130(11): $1327-1335$.

77. Naldini, L., Blomer, U., Gallay, P., Ory, D., Mulligan, R., Gage, F. H., Verma, I.M. \& Trono, D. 1996. In vivo gene delivery and stable transduction of nondividing cells by a lentiviral vector. Science, 272(5259): 263-267.

78. Negre, O., Bartholomae, C., Beuzard, Y., Cavazzana, M., Christiansen, L., Courne, C., Deichmann, A., Denaro, M., de Dreuzy, E., Finer, M., Fronza, R., Gillet-Legrand, B., Joubert, C., Kutner, R., Leboulch, P., Maouche, L., Paulard, A., Pierciey, F.J., Rothe, M., Ryu, B., Schmidt, M., von Kalle, C., Payen, E. \& Veres, G. 2015. Preclinical evaluation of efficacy and safety of an improved lentiviral vector for the treatment of betathalassemia and sickle cell disease. Current Gene Therapy, 15(1): 64-81.

79. Nisole, S. \& Saib, A. 2004. Early steps of retrovirus replicative cycle. Retrovirology, 1: 1-9.

80. Otsu, M., Nakajima, S., Kida, M., Maeyama, Y., Toita, N., Hatano, N., Kawamura, N., Kobayashi, R., Tatsuzawa, O. \& Onodera M. 2006. Stem Cell Gene Therapy with No PreConditioning for the ADA-Deficiency Patients Leads to Generalized Detoxification and Delayed, but Steady Hematological Reconstitution. Molecular Therapy, 13(S1): S418.

81. Ott, M. G., Schmidt, M., Schwarzwaelder, K., Stein, S., Siler, U., Koehl, U., Glimm, H., Kühlcke, K., Schilz, A., Kunkel, H., Naundorf, S., Brinkmann, A., Deichmann, A., Fischer, M., Ball, C., Pilz, I., Dunbar, C., Du, Y., Jenkins, N.A., Copeland, N.G., Lüthi, U., Hassan, M., Thrasher, A.J., Hoelzer, D., von Kalle, C., Seger, R. \& Grez, M. 2006. Correction of X-linked chronic granulomatous disease by gene therapy, augmented by insertional activation of MDS1-EVI1, PRDM16 or SETBP1. Nature Medicine, 12(4), 401-409.

82. Pauwels, K., Gijsbers, R., Toelen, J., Schambach, A., Willard-Gallo, K., Verheust, C., Debyser, Z. \& Herman, P. 2009. State-of-the-art lentiviral vectors for research use: risk assessment and biosafety recommendations. Current Gene Therapy, 9(6): 459-474.

83. Perumbeti, A., Higashimoto, T., Urbinati, F., Franco, R., Meiselman, H.J., Witte, D. \& Malik, P. 2009. A novel human gamma-globin gene vector for genetic correction of sickle cell anemia in a humanized sickle mouse model: critical determinants for successful correction. Blood, 114(6): 1174-1185.

84. Porteus, M. \& Carroll, D. 2005. Gene targeting using zinc finger nucleases. Nature, 23(8): 967-973.

85. Puthenveetil, G., Scholes, J., Carbonell, D., Qureshi, N., Xia, P., Zeng, L., Li S, Yu, Y., Hiti, A.L., Yee, J.K. \& Malik, P. 2004. Successful correction of the human betathalassemia major phenotype using a lentiviral vector. Blood, 104(12): 3445-3453.

86. Ribeil, J.A., Hacein-Bey-Abina, S., Payen, E., Magnani, A., Semeraro, M., Magrin, E., Caccavelli, L., Neven, B., Bourget, P., El Nemer, W., Bartolucci, P., Weber, L., Puy, H., Meritet, J.F., Grevent, D., Beuzard, Y., Chrétien, S., Lefebvre, T., Ross, R.W., Negre, O., Veres, G., Sandler, L., Soni, S., de Montalembert,
M., Blanche, S., Leboulch, P. \& Cavazzana, M. 2017. Gene Therapy in a Patient with Sickle Cell Disease. The New England Journal of Medicine, 376(9): 848-855.

87. Ringden, O., Remberger, M., Gustafsson, B., Moretti, G., Mattsson, J., Winiarski, J. \& Sadeghi, B. 2018. The Outcome of Allogeneic Hematopoietic Stem Cell Transplantation for Inherited Diseases Is Influenced by Hla Match, Year of Transplantation and Immunized Female Donor. https://doi.org/10.1097/TP.0000000000002481

88. Romero, Z., Urbinati, F., Geiger, S., Cooper, A.R., Wherley, J., Kaufman, M. L., Hollis, R.P., de Assin, R.R., Senadheera, S., Sahagian, A., Jin, X., Gellis, A., Wang, X., Gjertson, D., Deoliveira, S., Kempert, P., Shupien, S., Abdel-Azim, H., Walters, M.C., Meiselman, H.J., Wenby, R.B., Gruber, T., Marder, V., Coates, T.D. \& Kohn, D.B. 2013. Beta-globin gene transfer to human bone marrow for sickle cell disease. The Journal of Clinical Investigation. 123(8): 3317-3330.

89. Roselli, E.A., Mezzadra, R., Frittoli, M.C., Maruggi, G., Biral, E., Mavilio, F., Mastropietro, F., Amato, A., Tonon, G., Refaldi, C., Cappellini, M.D., Andreani, M., Lucarelli, G., Roncarolo, M.G., Marktel, S. \& Ferrari, G. 2010. Correction of beta-thalassemia major by gene transfer in haematopoietic progenitors of pediatric patients. $E M B O$ Molecular Medicine, 2(8): 315-328.

90. Rovelli, A.M. \& Steward, C.G. 2005. Hematopoietic cell transplantation activity in Europe for inherited metabolic diseases: open issues and future directions. Bone Marrow Transplant, 35 (Suppl 1): S23-26.

91. Royer-Pokora, B., Loos, U. \& Ludwig, W. D. 1991. TTG2 , a new gene encoding a cysteine-rich protein with the LIM motif, is overexpressed in acute T-cell leukaemia with the $\mathrm{t}(11 ; 14)(\mathrm{p} 13 ; \mathrm{q} 11)$. Oncogene, 6(10): 1887-1893.

92. Sanlioglu, S. 2016. Gen Tedavisi (Bölüm 20), In: Münis DÜNDAR Tibbl Genetik ve Klinik Uygulamalar: Akademisyen Kitabevi, 1221pp.

93. Santilli, G., Almarza, E., Brendel, C., Choi, U., Beilin, C., Blundell, M.P., Haria, S., Parsley, K.L., Kinnon, C., Malech, H.L., Bueren, J.A., Grez, M. \& Thrasher, A.J. 2011. Biochemical correction of X-CGD by a novel chimeric promoter regulating high levels of transgene expression in myeloid cells. Molecular Therapy, 19(1): 122-132.

94. Schambach, A., Swaney, W.P. \& van der Loo, J.C. 2009. Design and production of retro- and lentiviral vectors for gene expression in hematopoietic cells. Molecular Biology Reports, 506: 191-205.

95. Schambach, A., Zychlinski, D., Ehrnstroem, B. \& Baum, C. 2013. Biosafety features of lentiviral vectors. Human Gene Therapy, 24(2): 132-142.

96. Schwarzwaelder, K., Howe, S. J., Schmidt, M., Brugman, M. H., Deichmann, A., Glimm, H., Schmidt, S., Prinz, C., Wissler, M., King, D.J., Zhang, F., Parsley, K.L., Gilmour, K.C., Sinclair, J., Bayford, J., Peraj, R., Pike-Overzet, K., Staal, F.J., de Ridder, D., Kinnon, C., Abel, U., Wagemaker, G., Gaspar, H.B., Thrasher, A.J. \& von Kalle C. 2007. Gammaretrovirus-mediated correction of SCID-X1 is associated with skewed vector 
integration site distribution in vivo. The Journal of Clinical Investigation, 117(8): 2241-2249.

97. Serana, F., Sottini, A., Chiarini, M., Zanotti, C., Ghidini, C., Lanfranchi, A., Notarangelo, L.D., Caimi, L. \& Imberti L. 2010. The different extent of $\mathrm{B}$ and $\mathrm{T}$ cell immune reconstitution after hematopoietic stem cell transplantation and enzyme replacement therapies in SCID patients with adenosine deaminase deficiency. Journal of Immunology, 185(12): 7713-7722.

98. Shah, R. 2006. Regulatory framework for the treatment of orphan diseases. In Mehta A, Beck M \& S.-P. G (Eds.), Fabry Disease: Perspectives from 5 Years of FOS. Oxford: Oxford PharmaGenesis.

99. Shapiro, E., Krivit, W., Lockman, L., Jambaque, I., Peters, C., Cowan, M., Harris, R., Blanche, S., Bordigoni, P., Loes, D., Ziegler, R., Crittenden, M., Ris, D., Berg, B., Cox, C., Moser, H., Fischer, A. \& Aubourg, P. 2000. Long-term effect of bone-marrow transplantation for childhood-onset cerebral X-linked adrenoleukodystrophy. Lancet, 356(9231): 713-718.

100. Sharma, A., Jacob, A., Tandon, M. \& Kumar, D. 2010. Orphan drug: Development trends and strategies. Journal of Pharmacy and Bioallied Sciences, 2(4): 290-299.

101. Shaw, A. \& Cornetta, K. 2014. Design and Potential of Non-Integrating Lentiviral Vectors. Biomedicines, 2(1): 14-35.

102. Shimotohno, K. \& Temin, H.M. 1981. Formation of infectious progeny virus after insertion of herpes simplex thymidine kinase gene into DNA of an avian retrovirus. Cell, 26(1 Pt 1): 67-77.

103. Siler, U., Paruzynski, A., Holtgreve-Grez, H., Kuzmenko, E., Koehl, U., Renner, E. D., Alhan, C., de Loosdrecht, A.A., Schwäble, J., Pfluger, T., Tchinda, J., Schmugge, M., Jauch, A., Naundorf, S., Kühlcke, K., Notheis, G., Güngor, T., Kalle, C.V., Schmidt, M., Grez, M., Seger, R. \& Reichenbach, J. 2015. Successful Combination of Sequential Gene Therapy and Rescue Allo-HSCT in Two Children with X-CGD-Importance of Timing. Current Gene Therapy, 15(4): 416-427.

104. Sinn, P.L., Sauter, S.L. \& McCray, P.B. Jr. 2005. Gene therapy progress and prospects: development of improved lentiviral and retroviral vectors--design, biosafety, and production. Gene Therapy, 12(14): 1089-1098.

105. Sokolic, R., Kesserwan, C., \& Candotti, F. 2008. Recent advances in gene therapy for severe congenital immunodeficiency diseases. Current Opinion in Hematology, 15(4): 375-380.

106. Stein, S., Ott, M.G., Schultze-Strasser, S., Jauch, A., Burwinkel, B., Kinner, A., Schmidt, M., Krämer, A., Schwäble, J., Glimm, H., Koehl, U., Preiss, C., Ball, C., Martin, H., Göhring, G., Schwarzwaelder, K., Hofmann, W.K., Karakaya, K., Tchatchou, S., Yang, R., Reinecke, P., Kühlcke, K., Schlegelberger, B., Thrasher, A.J., Hoelzer, D., Seger, R., von Kalle, C. \& Grez, M. 2010. Genomic instability and myelodysplasia with monosomy 7 consequent to EVI1 activation after gene therapy for chronic granulomatous disease. Nature Medicine, 16(2): 198-204.

107. European Medicines Agency, 2016. Strimvelis, autologous CD34+ enriched cell fraction that contains CD34+ cells transduced with retroviral vector that encodes for the human ADA cDNA sequence, European Public Assessment Report [EMA/CHMP/323455/2016]. Available from: http://www. ema.europa.eu/docs/en_GB/document_library/EPAR__Public_assessment_report/human/003854/WC50020820 1.pdf

108. Temin, H.M. 1990. Safety considerations in somatic gene therapy of human disease with retrovirus vectors. Human Gene Therapy, 1(2): 111-123.

109. Thompson, A.A., Kwiatkowski, J., Rasko, J., Hongeng, S., Schiller, G.J., Anurathapan, U., Cavazzana, M., Ho, P.J., von Kalle, C. \& Kletzel M. 2016. Lentiglobin Gene Therapy for Transfusion-Dependent $\beta$-Thalassemia: Update from the Northstar Hgb-204 Phase 1/2 Clinical Study. Blood, 128(22): 1175-1175.

110. Thrasher, A.J., Hacein-Bey-Abina, S., Gaspar, H.B., Blanche, S., Davies, E.G., Parsley, K., Gilmour, K., King, D., Howe, S., Sinclair, J., Hue, C., Carlier, F., von Kalle, C., de Saint Basile, G., le Deist, F., Fischer, A. \& Cavazzana-Calvo, M. 2005. Failure of SCID-X1 gene therapy in older patients. Blood, 105(11): 4255-4257.

111. US Orphan Drug Act, 1983. from http://www.fda.gov/orphan/lawsregs.html

112. Vink, C.A., Counsell, J.R., Perocheau, D.P., Karda, R., Buckley, S.M.K., Brugman, M.H., Galla, M., Schambach, A., McKay, T.R., Waddington, S.N. \& Howe S.J. 2017. Eliminating HIV-1 Packaging Sequences from Lentiviral Vector Proviruses Enhances Safety and Expedites Gene Transfer for Gene Therapy. Molecular Therapy, 25(8): 1790-1804.

113. Wanisch, K. \& Yanez-Munoz, R.J. 2009. Integrationdeficient lentiviral vectors: a slow coming of age. Molecular Therapy, 17(8): 1316-1332.

114. Wei, C.M., Gibson, M., Spear, P.G. \& Scolnick, E.M. 1981. Construction and isolation of a transmissible retrovirus containing the src gene of Harvey murine sarcoma virus and the thymidine kinase gene of herpes simplex virus type 1. Journal of Virology, 39(3): 935-944.

115. Wynn, R. 2011. Stem cell transplantation in inherited metabolic disorders. Hematology the American Society of Hematology Education Program, 2011: 285-291.

116. Zufferey, R., Nagy, D., Mandel, R. J., Naldini, L. \& Trono, D. 1997. Multiply attenuated lentiviral vector achieves efficient gene delivery in vivo. Nature Biotechnology, 15(9): 871-875.

117. Zychlinski, D., Schambach, A., Modlich, U., Maetzig, T., Meyer, J., Grassman, E., Mishra, A. \& Baum C. 2008. Physiological promoters reduce the genotoxic risk of integrating gene vectors. Molecular Therapy, 16(4): 718725 . 